\title{
Rancang Bangun Sistem Absensi Mahasiswa Menggunakan Sensor RFID dengan Database MySQL XAMPP dan Interface Visual Basic
}

\author{
Ayu Azura*, Wildian \\ Laboratorium Elektronika dan Instrumentasi, Jurusan Fisika \\ Fakultas Matematika dan Ilmu Pengetahuan Alam, Universitas Andalas \\ Kampus Limau Manis, Padang, 25163, Indonesia \\ *ayuazura666@gmail.com
}

\begin{abstract}
ABSTRAK
Perancangan sebuah prototipe sistem absensi mahasiswa telah dilakukan menggunakan sensor Radio Frequency Identification (RFID). Sistem RFID ini terdiri dari komponen tag dan reader. Tag digunakan sebagai pengganti ID card dan reader digunakan untuk membaca informasi menyangkut kehadiran mahasiswa. Alat yang dirancang terintegrasi dengan database kehadiran mahasiswa pada suatu matakuliah sehingga dapat berperan sebagai pengganti sistem absensi manual. Database kehadiran dibuat dengan MySQL XAMPP. Graphical User Interface (GUI) digunakan untuk interface antara pengguna dan database dengan format yang terdiri dari formportserial, forminputdata dan formdatabase. Sistem yang terintegrasi dengan database memungkinkan data untuk langsung disimpan secara otomatis ke dalam database sehingga memudahkan admin merekap kehadiran mahasiswa. Hasil pengujian terhadap lima kartu RFID menunjukkan bahwa reader memiliki kemampuan jarak baca maksimum $4 \mathrm{~cm}$ dengan tegangan keluaran RFID reader $\geq 3,2 \mathrm{~V}$. Interval waktu pembacaan antara satu kartu dengan kartu berikutnya minimal 2 detik. Alat yang dirancang mampu memberikan keterangan hadir dan tidak hadir berdasarkan batas toleransi keterlambatan yang ditentukan. Penggunaan Real Time Clock DS1307 yang dapat bekerja selama maksimum satu jam.

Kata kunci: database MySQL XAMPP, Radio Frequency Identification, Visual Basic
\end{abstract}

\begin{abstract}
The design of a student attendance prototype system has been done using Radio Frequency Identification (RFID) sensors. This RFID system consists of tag and reader components. Tag are used instead of ID cards and readers are used to read information regarding student attendance. The tool designed is integtared with the student attendance database in a course so that it can act as a substitute of manual attendance system. Attendance database created with MySQL XAMPP. Graphical User Interface (GUI) is used to interface between users and databases with formats consisting of formportserial, forminputdata and formdatabase. The integrated system with the database allows the data to be direct stored automatically into the database making it easier for the admins to absorb student attendance. Test results on five RFID cards indicate that the reader has a maximum read-distance capability of $4 \mathrm{~cm}$ with output voltage $\geq .3,2 \mathrm{~V}$. Interval time of reading between one card with the next card at least 2 seconds. The design tool is capable of providing present and absent information based on specified delay tolerance limits. The use of Real Time Clock DS1307 can work for a maximum of one hour.

Keywords: database MySQL XAMPP, Radio Frequency Identification, Visual Basic
\end{abstract}

\section{PENDAHULUAN}

Absensi merupakan suatu aktivitas pelaporan dan pendataan kehadiran yang ada dalam sebuah institusi (Setiawan dan Kurniawan, 2015). Berdasarkan cara penggunaannya, sistem absensi dapat dikelompokkan menjadi manual dan digital. Sistem absensi manual yang dilakukan di perguruan tinggi mengharuskan mahasiswa mengisi formulir absensi dengan tandatangan pada saat perkuliahan (Yusuf, 2016). Sistem ini memiliki beberapa kekurangan seperti adanya penitipan tandatangan, memerlukan banyak kertas dan tinta, dan membutuhkan ruang yang banyak sebagai tempat penyimpanan. Kekurangan-kekurangan tersebut dapat diatasi dengan memanfaatkan teknologi yang dipadukan dengan sistem RFID. Sistem ini terdiri dari RFID reader dan tag yang dapat dikembangkan sebagai mesin absensi mahasiswa pada saat perkuliahan (Hamdani, 2014).

Penelitian mengenai sistem absensi mahasiswa secara digital telah dilakukan oleh beberapa peneliti. Sistem yang dirancang oleh Susanto (2009) adalah sistem absensi portabel yang menggunakan RFID tag sebagai identifikasi kehadiran mahasiswa dan dilengkapi dengan Real Time Clock DS1307 yang dapat membatasi keterlambatan mahasiswa. Daftar hadir ditampilkan dalam database, namun database yang dimunculkan hanya berupa keluaran nomor 
ID, waktu, tanggal, dan tingkat keberhasilan input data. Data yang diperoleh tidak akurat karena pemilik nomor ID tidak ada dalam database sehingga harus dikenali dulu pemilik masing-masing nomor ID tersebut.

Sistem absensi digital dirancang juga oleh Sabil (2016) menggunakan RFID yang terintegrasi dengan database, perangkat lunak Visual Studio, Microsoft Access dan Microsoft Excel. Alat yang dirancang ini belum bisa membatasi keterlambatan mahasiswa. Penelitian yang sama juga dilakukan oleh Sukowati (2017) dimana datanya terintegrasi dengan Sistem Informasi Akademik (SIA) dan perangkat lunak yang digunakan Visual Basic dan database MySQL. Kelemahan penelitian ini adalah penggunaan SIA yang hanya bisa diakses oleh pihakpihak tertentu dan membutuhkan koneksi internet.

Berdasarkan permasalahan yang telah diuraikan, maka dilakukan penelitian untuk merancang bangun sistem absensi mahasiswa menggunakan sensor RFID. Sistem terintegrasi langsung dengan database MySQL XAMPP dan Visual Basic sebagai interface. Database yang ditampilkan dapat memberikan keterangan hadir dan tidak hadirnya mahasiswa pada suatu mata kuliah. Kartu RFID didekatkan pada RFID reader, proses pengiriman dan penerimaan data dapat terjadi jika frekuensi yang dipancarkan mencapai frekuensi resonansi. Penelitian ini bertujuan untuk merancang bangun sistem absensi mahasiswa menggunakan RFID berbasis Arduino Uno R3 dan Real Time Clock DS1307 dengan perangkat lunak Visual Basic dan database MySQL XAMPP.

\section{METODE}

\subsection{Perancangan Sistem Diagram Blok}

Sistem absensi ini dimulai dengan pembacaan RFID tag oleh RFID reader. Keberhasilan pembacaan RFID ditandai dengan munculnya nomor ID pada serial monitor Arduino Uno R3. Selanjutnya ditampilkan pada antarmuka di XAMPP dan data masuk secara otomatis pada penyimpanan database MySQL sebagai output dari sistem absensi. Diagram blok sistem dapat dilihat pada Gambar 1.

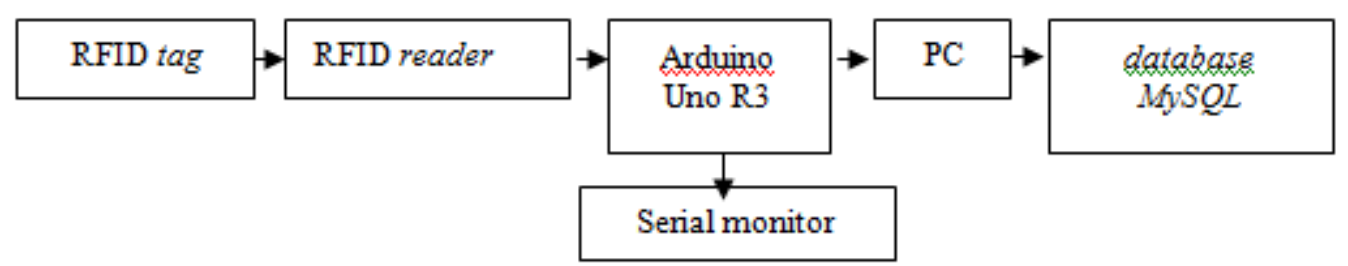

Gambar 1 Skema diagram blok sistem

\subsection{Perancangan Bentuk Fisik Alat}

Skema bentuk fisik ditunjukkan pada Gambar 2. Rangkaian diletakkan dalam sebuah kotak. RFID reader berada diposisi luar agar tidak ada halangan atau hambatan untuk mendeteksi nomor ID RFID card.

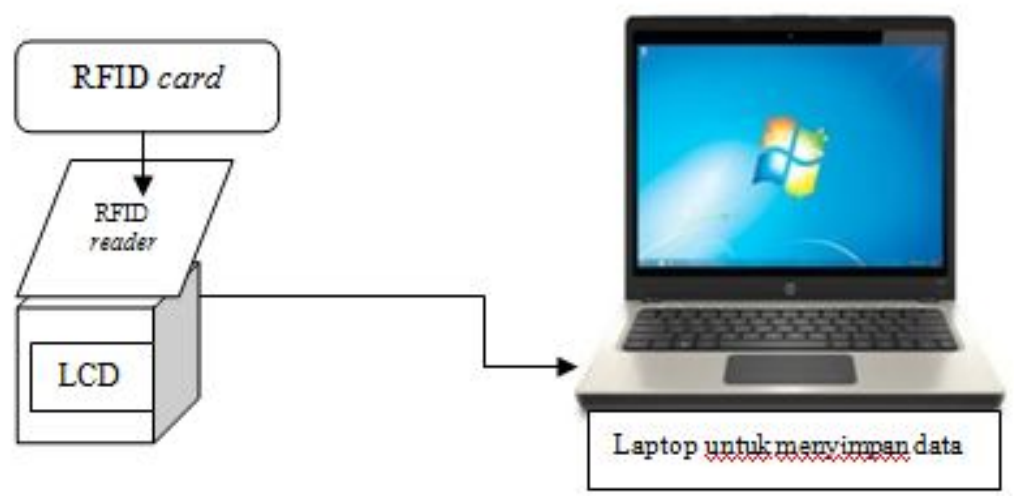

Gambar 2 Skema bentuk fisik alat 


\subsection{Perancangan Diagram Alir}

Sistem diprogram pada Arduino Uno R3 menggunakan Arduino IDE 1.8.5. Absensi yang diproses adalah mahasiswa yang mendekatkan kartu RFID dengan RFID reader dalam batas toleransi keterlambatan (15 menit). Pada saat kartu didekatkan, maka kartu akan terjadi identifikasi kartu dan terhubung ke serial port serta data akan masuk. Jika data sesuai dengan database maka akan diproses langsung dengan tampilan database MySQL. Jika absensi dilakukan di luar batas toleransi, maka muncul keterangan tidak hadir pada database. Diagram alir program dapat dilihat pada Gambar 3.

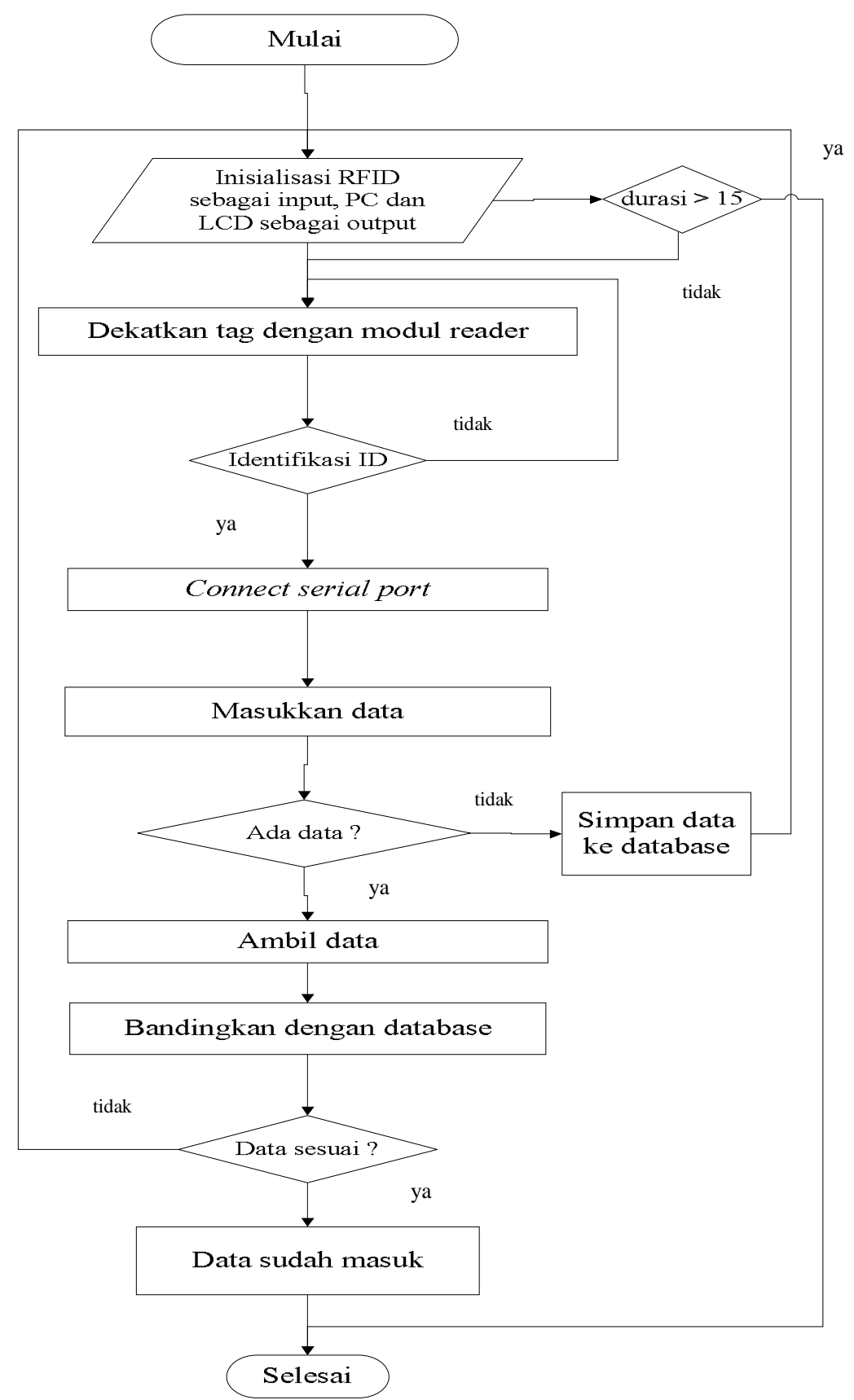

Gambar 3 Diagram alir sistem

\subsection{Pengujian Alat}

Pengujian alat dilakukan dengan 5 buah kartu, masing-masing dengan 10 variasi jarak dari 1-10 cm. Proses ini dilakukan dengan mendekatkan kartu RFID dengan RFID reader, masing-masing kartu dengan nomor ID yang berbeda-beda. Pembacaan nomor ID terjadi jika 
frekuensi yang dipancarkan kartu RFID dan RFID reader mencapai frekuensi resonansi seperti Persamaan 1.

$$
f_{\text {res }}=\frac{1}{2 \pi \sqrt{L C}}
$$

dengan $f_{\text {res }}$ adalah frekuensi resonansi (hertz), $L$ adalah induktansi (hendry) dan $C$ adalah kapasitansi (farad).

\section{HASIL DAN DISKUSI}

\subsection{Hasil Karakterisasi Sensor RFID MFRC 522}

Proses pengambilan data karakterisasi sensor RFID MFRC522 dilakukan dengan cara membandingkan jarak baca kartu oleh RFID reader terhadap tegangan keluaran yang dihasilkan oleh RFID reader. Karakterisasi dilakukan pada 5 buah kartu RFID dengan jarak yang berbeda-beda. Pengujian dilakukan pada jarak 1-10 $\mathrm{cm}$ dengan grafik yang dapat dilihat pada Gambar 4.

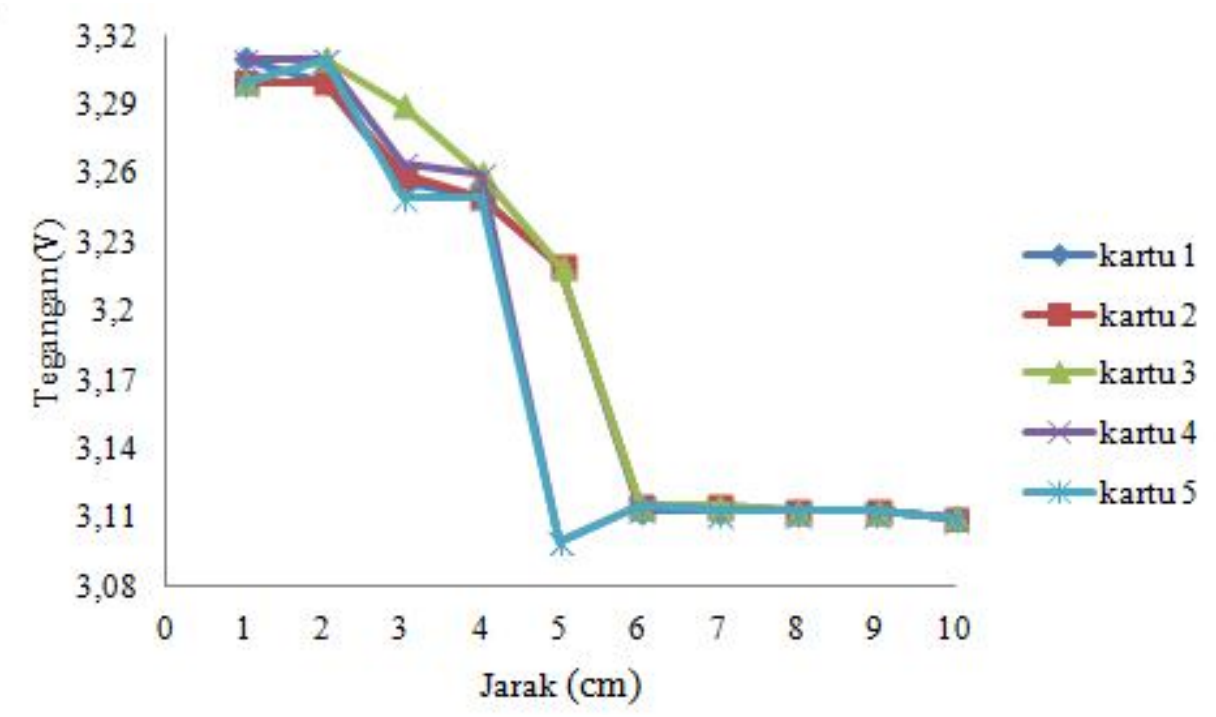

Gambar 4 Grafik jarak baca kartu RFID terhadap tegangan keluaran RFID reader

Grafik di atas menunjukkan bahwa semakin dekat jarak baca kartu RFID dengan RFID reader, maka tegangan keluaran RFID reader mencapai tegangan maksimum. Pengujian dilakukan pada lima kartu, untuk kartu 4 dan 5 dengan jarak baca $5 \mathrm{~cm}$ tidak dapat diidentifikasi karena tegangan keluarannya $<3,2 \mathrm{~V}$. Untuk jarak baca $6-10 \mathrm{~cm}$ juga tidak dapat diidentifikasi karena tegangan keluarannya $<3,2 \mathrm{~V}$.

\subsection{Hasil Pengujian Real Time Clock dan LCD}

Pengujian RTC dilakukan dengan menanamkan program ke dalam mikrokontroler ATmega328 yang ada pada board Arduino Uno R3. Program yang ditanamkan ke dalam mikrokontroler adalah program untuk menampilkan waktu, hari dan tanggal pada LCD. Proses ini bertujuan untuk mengetahui apakah RTC dapat berfungsi dengan baik. Pengujian ini dapat dilihat pada Gambar 5. Setelah program ditanamkan, RTC dapat menampilkan keluarannya pada tampilan LCD dan bekerja secara maksimum selama satu jam, jika RTC dimatikan alat berhenti bekerja. Hal ini mungkin disebabkan baterai RTC tidak berfungsi dengan baik. 


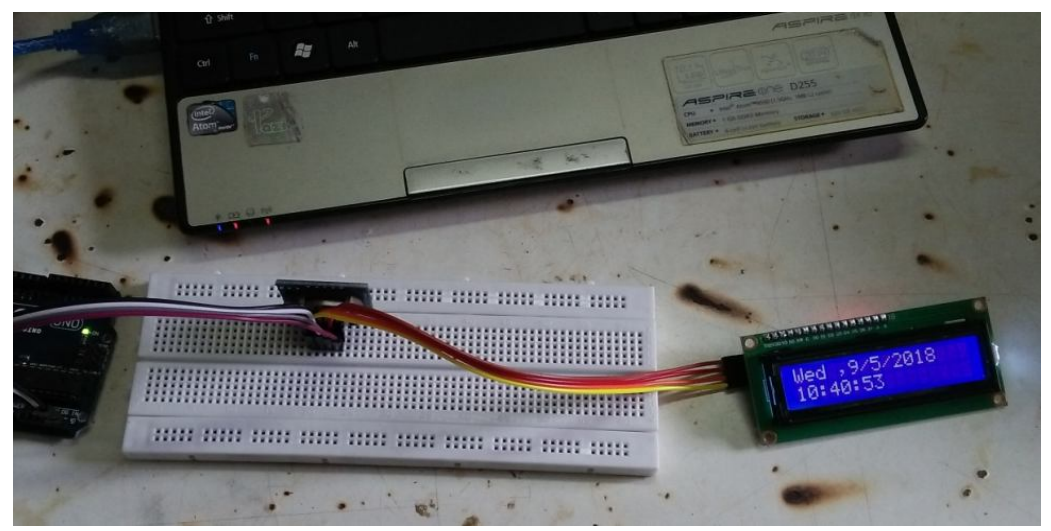

Gambar 5 Tampilan keluaran RTC pada LCD

\subsection{Tampilan Database Absensi}

Tampilan interface database absensi yang telah dibuat menggunakan Visual Basic 6.0. Interface ini adalah antarmuka sistem dan database.

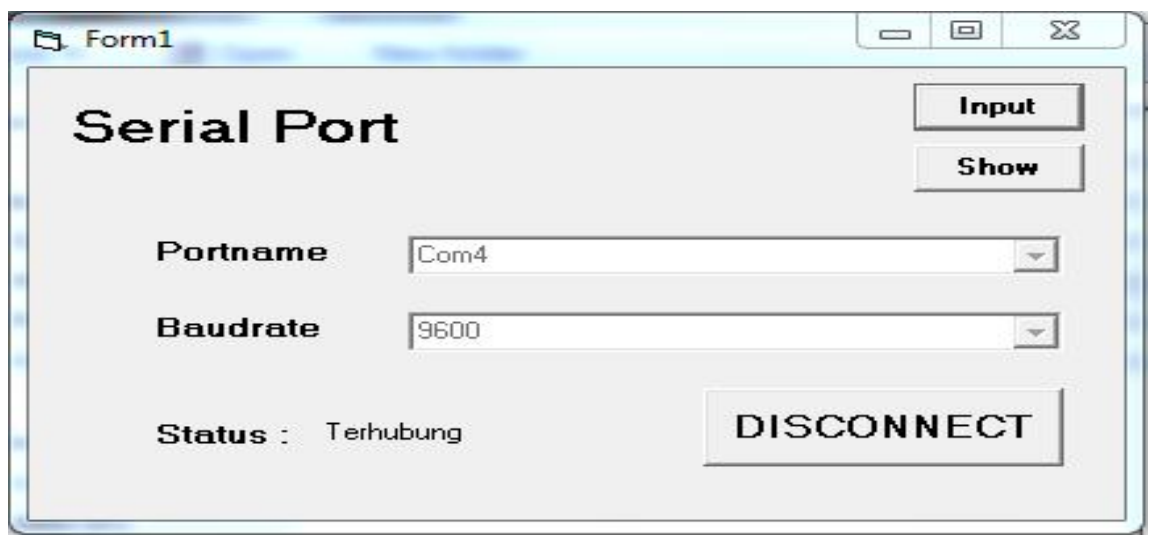

Gambar 6 Form serial port

Form serial port Gambar 6 menunjukkan port dan baudrate yang digunakan. Pada penelitian ini port yang digunakan adalah port com4 dan menggunakan baudrate 9600 . Jika port dan baudrate yang dimasukkan sesuai maka status terhubung.

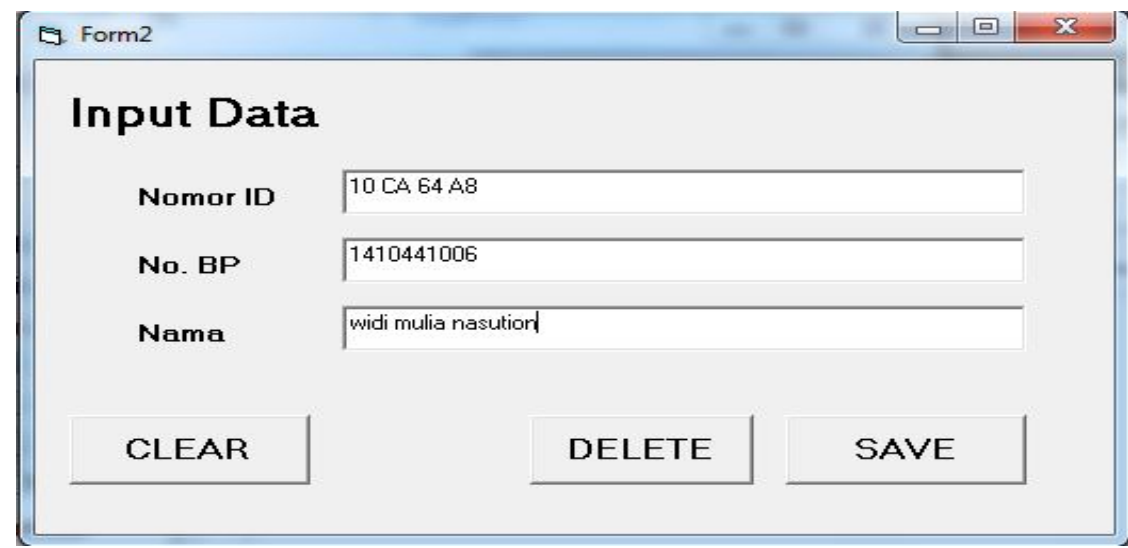

Gambar 7 Form input data

Form input data Gambar 7 merupakan form yang digunakan untuk memasukkan data mahasiswa. Data mahasiswa dimasukkan ke database berdasarkan matakuliah yang bersangkutan. Database terintegrasi langsung dengan sistem, sehingga sistem bekerja dan mendeteksi nomor ID kartu. Nomor ID yang sesuai dengan database diproses dan disimpan, jika nomor ID tidak sesuai maka data harus dimasukkan pada form input data. 


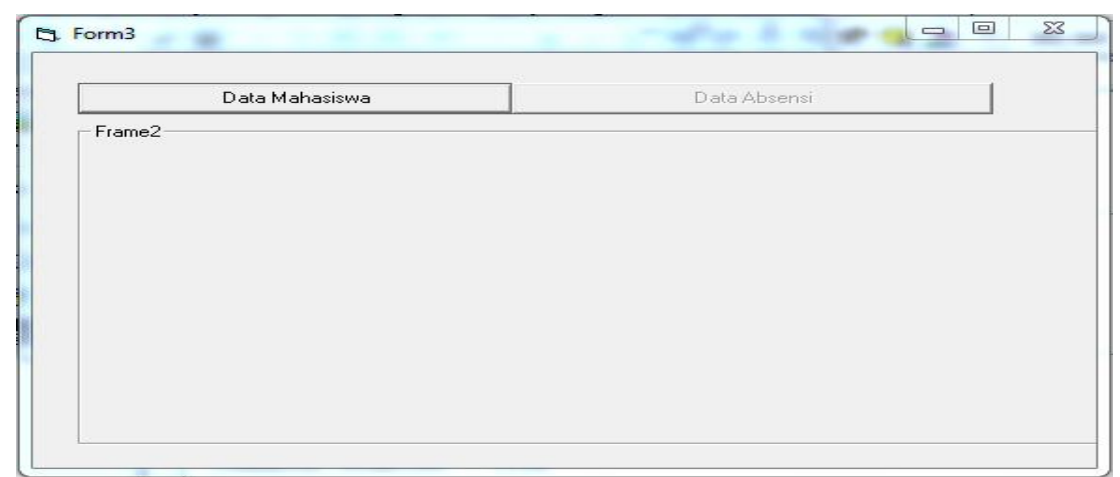

Gambar 8 Form data mahasiswa

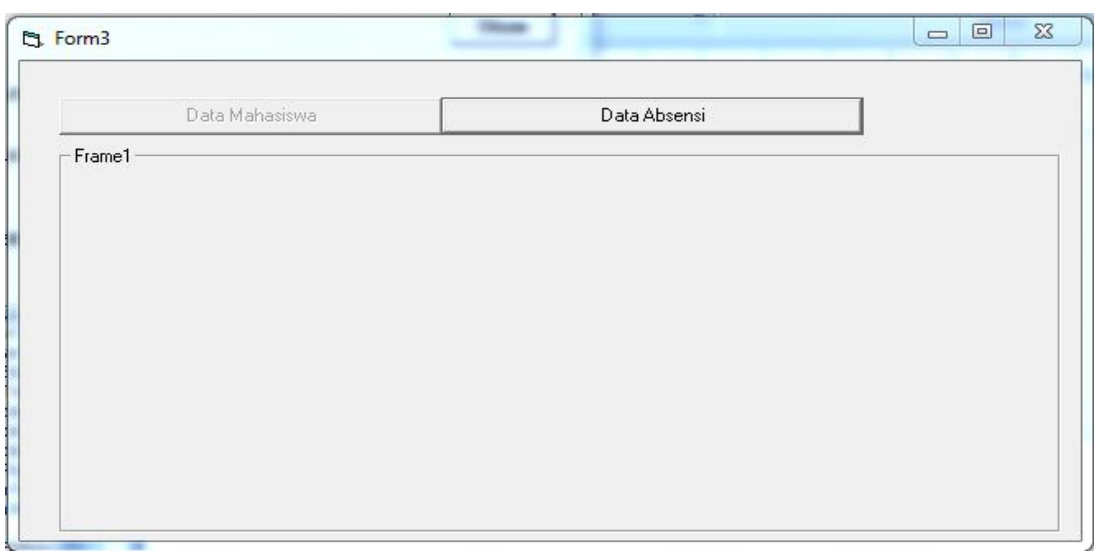

Gambar 9 Form data absensi

Form data mahasiswa Gambar 8 adalah pilihan untuk menampilkan data mahasiswa yang sudah dimasukkan pada form input data. Form data absensi Gambar 9 untuk menampilkan data mahasiswa, tanggal dan keterangan hadir dan tidak hadirnya mahasiswa.

\subsection{Pengujian Rancang Alat Secara Keseluruhan}

Pengujian sistem absensi pada alat menghasilkan keluaran yang ditampilkan dalam database MySQL XAMPP. Tampilan database berdasarkan menu yang dipilih yaitu menu data mahasiswa atau menu data absensi. Tampilan keluaran data mahasiswa dapat dilihat pada Gambar 10.

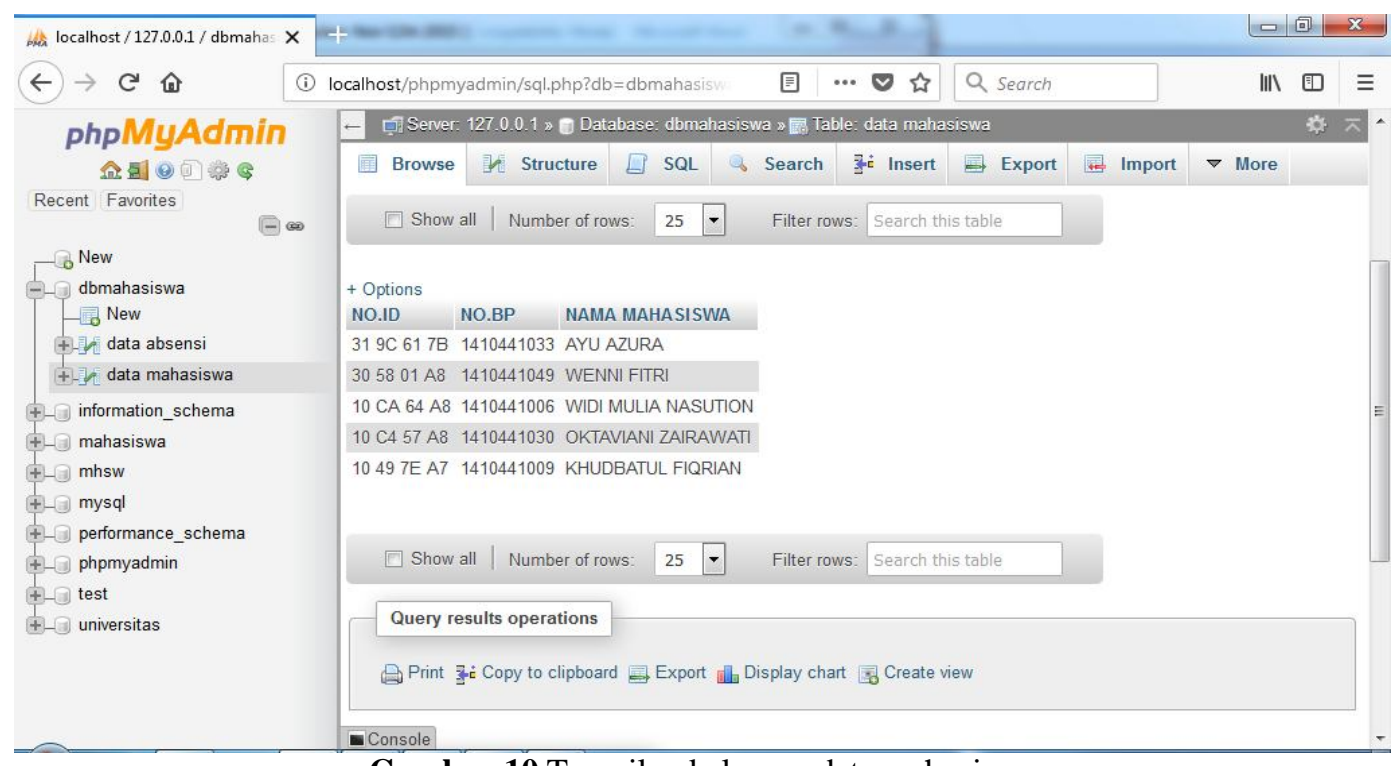

Gambar 10 Tampilan keluaran data mahasiswa 
Gambar di atas menunjukkan keluaran pada pemilihan menu data mahasiswa. Data mahasiswa ini diperoleh dari data yang dimasukkan pada interface Visual Basic. Menu data mahasiswa ini digunakan untuk melihat data yang sudah dimasukkan pada proses awal sebelum sistem dijalankan.

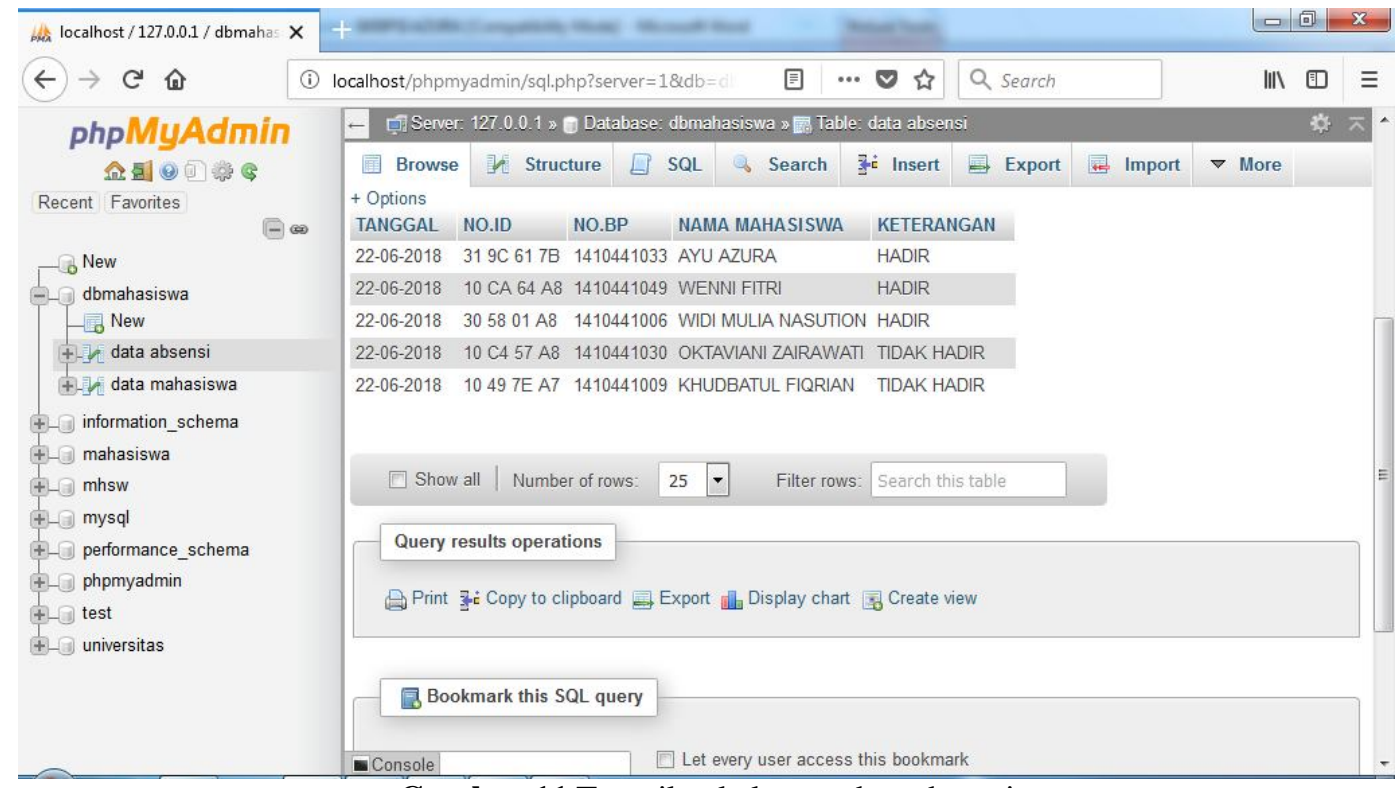

Gambar 11 Tampilan keluaran data absensi

Sistem yang dirancang dapat mengatur batas keterlambatan maksimum. Gambar 11 menunjukkan data mahasiswa yang dilengkapi dengan tanggal absensi dan keterangan hadir dan tidak hadir. Keterangan hadir muncul jika absensi dilakukan sebelum batas waktu yang ditetapkan (15 menit) dan jika absensi dilakukan setelah 15 menit maka muncul keterangan tidak hadir pada database. Menu data absensi ini digunakan pada saat rekap akhir daftar hadir mahasiswa.

\section{KESIMPULAN}

Berdasarkan hasil pengujian pada sistem yang telah dirancang bangun, sistem yang dibuat telah berhasil. Hal ini ditunjukkan dengan sistem yang mampu mendeteksi nomor ID kartu dan menyatakan mahasiswa hadir atau tidak hadirnya dengan toleransi waktu yang ditetapkan. Sistem hanya mendeteksi masukan satu kartu dan tidak bisa mendeteksi masukan yang lebih dari satu. Jeda waktu pembacaan kartu satu dengan kartu berikutnya minimal 2 detik. Kartu RFID yang digunakan dapat diidentifikasi pada saat tegangan keluaran RFID reader $\geq$ 3,2 V dengan jarak baca maksimum reader terhadap kartu adalah $4 \mathrm{~cm}$. Real Time Clock DS1307 yang digunakan dapat bekerja selama maksimum satu jam dan tidak berfungsi jika dimatikan meskipun ada baterai.

\section{DAFTAR PUSTAKA}

Hamdani, F., "Penerapan RFID di Perpustakaan:Kelebihan dan Kekurangannya", (Jurnal Ilmu Perpustakaan dan Kearsipan Khizanah Al-Hikmah, UIN Syarif Hidayatullah, 2014), hal.71-79.

Sabil, F.H., "Rancang Bangun Alat Sistem Absensi Mahasiswa Menggunakan RFID (Radio Frequency Identification) Berbasis Mikrokontroler Atmega328 dengan Compiler Arduino Uno", Skripsi S1, Universitas Sumatera Utara, 2016.

Setiawan, E.B. dan Kurniawan, B., "Perancangan Sistem Absensi Kehadiran Perkuliahan dengan Menggunakan Radio Frequency Identification (RFID)”, (Jurnal CoreIT, Bandung, 2015), hal.44-49.

Sukowati, A.I., "Rancang Bangun Sistem Absensi Mahasiswa Sekolah Tinggi Teknik Cendekia (STTC) Berbasis Radio Frequency Identification (RFID) Menggunakan Arduino Uno 
R3", (Jurnal Ilmiah Komputasi, Sekolah Tinggi Teknik Multimedia Cendekia Abditama, 2017), hal.93-100.

Susanto, R., "Sistem Absensi Berbasis RFID”, (Jurnal Teknik Komputer, Jakarta, 2009), hal.67-74.

Yusuf, M., "Rancang Bangun Aplikasi Absensi Perkuliahan Mahasiswa dengan Pengenalan Wajah", (Jurnal Teknik ITS, Jurusan Teknik Informatika, 2016), hal.66-70. 